\title{
ОГЛЯД СУЧАСНИХ АСПЕКТІВ ПРОФІЛАКТИКИ СЕРЦЕВО-СУДИННИХ ЗАХВОРЮВАНЬ У ВІЙСЬКОВОСЛУЖБОВЦІВ ЗБРОЙНИХ СИЛ УКРАЇНИ
}

\author{
Т.В. Куц, Г.3. Мороз, І. М. Ткачук
}

\author{
Українська військово-медична академія, м. Київ, Украӥна
}

\begin{abstract}
Мета дослідження: провести аналіз та узагальнення даних літературних джерел щодо сучасного стану профілактики серцево-судинних захворювань у військовослужбовців Збройних Сил України.

Матеріали та методи. Аналітична база даних сформована з 80 наукових праць, в тому числі нормативно-правових документів і статистично-довідкових матеріалів (з них 4 - англомовних). Огляд літератури здійснено з використанням системного підходу та системного аналізу, бібліосемантичного методу.
\end{abstract}

Результати. Огляд літератури показав позитивні тенденції в системі профілактики серцевосудинних захворювань у військовослужбовців Збройних Сил України, а саме: розроблена та запроваджена функціонально-організаційна модель профілактики серцево-судинних захворювань у військовослужбовців на рівні первинної медичної допомоги; розроблене навчально-методичне забезпечення щодо удосконалення підготовки військових лікарів загальної практики-сімейної медицини та молодших спеціалістів з медичною освітою з питань профілактики серцево-судинних захворювань; запроваджено методичне забезпечення підвищення поінформованості військовослужбовців з питань здорового способу життя; створено на базі Клініки амбулаторної допомоги Національного військово-медичного клінічного центру «ГВКГ» «Школи здоров'я для хворих на артеріальну гіпертензію військовослужбовців з коморбідними тривожними $i$ депресивними розладами» та запроваджено комплексний підхіду до організації лікування та реабілітації військовослужбовців-учасників бойових дій з артеріальною гіпертензією. Проте існує низка проблемних питань, які потребують вирішення: необхідно створити галузевий клінічний протокол щодо профілактики серцево-судинних захворювань у військовослужбовців; не регламентовано проведення виявлення факторів ризику серцево-судинних захворювань призовникам на рівні військових комісаріатів; не визначено роль і місце цивільних закладів охорони здоров'я та закладів освіти, громадських і волонтерських організацій в реалізації профілактики серцево-судинних захворювань в період до призову в лави Збройних сил України.

Висновки. Узагальнення сучасних наукових даних показало, що існуюча система профілактики серцево-судинних захворювань у військовослужбовців потребує удосконалення відповідно до стандартів НАТО, де найважливіше місце займають превентивні заходи.

Ключові слова: військовослужбовці, профілактика, серцево-судинні захворювання.

Вступ. На сучасному етапі реформування Збройних Сил (3С) України головним завданням є перехід усіх ключових функцій сил оборони до стандартів НАТО, що означає якісну трансформацію діяльності ЗС України [37]. Військова медицина, перш за все, потребує розробки та запровадження стандартизованих підходів надання медичної допомоги, які відповідають вимогам доказової медицини та стандартам НАТО [8]. У Доктрині НАТО 3 медичного забезпечення AJP-4.10, видання В, версія 1 (2015) $[77,78]$, зазначено, що «слід докласти усіх сил, щоб медична допомога, грунтувалася на міжнародних передових медичних практиках». Такий підхід розглядається як важлива частина «Концепції Програми розвитку системи медичного забезпечення Збройних Сил України на період до 2020 року, затвердженої наказом Міністерства оборони (М0) України № 389 від 26.07.2017 [46]. Враховуючи високі рівні захворюваності, дискваліфікації, смертності військовослужбовців з приводу класу хвороб системи кровообігу (ХСК) [17, 29], існує необхідність визначення проблемних аспектів в профілактиці даного класу хвороб на сучасному етапі.

Мета дослідження: провести аналіз та узагальнення даних літературних джерел щодо сучасного стану профілактики серцевосудинних захворювань у військовослужбовців ЗС України

Матеріали та методи дослідження: бібліосемантичний, порівняльний та системного підходу.

Результати дослідження та їх обговорення. Умови військової праці, складний i напружений характер сучасної війни пред'являють до військовослужбовця підвищені вимоги, які можуть бути виконані за умови повного його фізичного і психічного здоров'я та соціального добробуту, досягнення яких можливе лише за 
концентрації зусиль медичної служби і командування [72].

Важливою складовою 3С України $є$ військово-медична служба. Здійснюючи безперервне піклування про збереження та зміцнення здоров'я особового складу військ, участь у підтриманні постійної боєздатності особового складу, медична служба здійснює вагомий внесок в забезпечення бойової потужності та високої боєздатності ЗС України $[5,6,41]$.

\section{Професійне}

здоров'я військовослужбовця та його професійна надійність розглядається, як відсутність захворювань при наявності певного рівня компенсаторних та захисних механізмів, що забезпечують високу боєздатність (працездатність) в умовах його професійної діяльності. Забезпечення необхідного рівня здоров'я особового складу розглядається як остаточна мета військової 03, адже від цього залежить стан боєздатності особового складу, як визначального чинника бойової готовності військ $[31,53]$.

Україна все більше співпрацює 3 інституціями ООН, НАТО. В «Доктрині НАТО 3 медичного забезпечення», в документі «Принципи i політика медичного забезпечення операцій НАТО» та «Керівництві 3 медичного забезпечення миротворчих операцій ООН» зазначено, що професійне здоров'я є важливою складовою боєздатності військовослужбовців. [77, 78, 80]. Основний напрям розвитку ЗС України спрямований на євроатлантичну інтеграцію як визначальний фактор гарантування безпеки та територіальної цілісності України [50]. Невід'ємною частиною реформування 3С України є проведення реформ і у військовій охороні здоров'я $[11,73]$. «Воєнно-медична доктрина» $\epsilon$ базовим науково-практичним документом непрямої дії для медичної служби 3С України та посідає місце основного доктринального документу щодо медичного забезпечення військ (сил) та є основою для розроблення інших керівних документів 3 питань медичного забезпечення [3]. Доктрина медичного забезпечення містить науково обгрунтовані принципи, вимоги і стандарти, які визначають структурно-функціональний вигляд системи медичного забезпечення ЗС та відповідають конкретним історичним умовам [41]. У мирний час діяльність медичної служби 3С України будується на тих же організаційних, наукових i практичних основах, що i загальна система охорони здоров'я країни, але з урахуванням специфіки діяльності військовослужбовців та їх побуту. Завдання медичної служби у повсякденних умовах включають організацію контролю за відбором контингентів, які підлягають призову на військову службу, здійснення лікувально-профілактичних, санітарногігієнічних, протиепідемічних заходів, навчання військовослужбовців прийомам само- і взаємодопомоги, щеплення їм навичок профілактики захворювань, забезпечення військ медичним майном та ін. Пріоритетами медичного забезпечення ЗС України у мирний час виступають першорядна роль профілактичних заходів і програм здорового способу життя [41]. При цьому варто підкреслити, що у військових підрозділах і частинах ЗС США обсяг заходів превентивної медицини і їхня значимість перевищує всі інші розділи військової охорони здоров'я. Персонал превентивної медицини $\epsilon$ радником командування з питань охорони здоров'я i добробуту особового складу. У ЗС країн НАТО командири всіх рангів несуть персональну відповідальність за збереження здоров'я i життя особового складу [72]. Одним із напрямків реформування системи медичного забезпечення ЗС України $\epsilon$ впровадження стандартів медичного забезпечення $3 \mathrm{C}$ України НАТО до 2020 р. [2, 7, 12, 14, 28, 50].

у зв'язку з необхідністю подальшого удосконалення та розвитку системи медичного забезпечення 3С затверджено наказом МО України № 389 від 26.07.2017 «Концепцію програми розвитку системи медичного забезпечення Збройних Сил України на період до 2020 року» [46], яка $€$ частиною «Державної програми розвитку Збройних Сил України на період до 2020 року», затвердженої Указом Президента України від 22.03.2017 № 73/2017 [51]. Згідно Наказу № 389 від 26.07.2017 [46] пріоритетним напрямом вважається розроблення вітчизняних військово-медичних стандартів шляхом вивчення та імплементації стандартів медичного забезпечення військ держав-членів НАTO.

Одним із визначальних механізмів державного регулювання якості медичної допомоги $є$ стандартизація, яка спрямована на досягнення оптимального ступеня впорядкування в системі охорони здоров'я (03) шляхом розробки і встановлення вимог, норм, правил, технологій, робіт, послуг, що застосовуються в 03 [18, 20, 60]. Кабінет Міністрів України Розпорядженням від 
15.11.2017 № 821-р «Про затвердження плану заходів 3 реалізації Концепції реформи фінансування системи охорони здоров'я на період до 2020 року» [48] затвердив план заходів 3 реалізації Концепції реформи фінансування системи охорони здоров'я на період до 2020 року, в якому зазначено здійснення перекладу та адаптації міжнародних уніфікованих клінічних протоколів для України. Таким чином, в Україні актуальним питанням залишається процес гармонізації медико-технологічних документів. Проблема стандартизації в 3С стала найбільш актуальною на етапі досягнення медичною службою ЗС України критеріїв відповідності стандартам медичного забезпечення ЗС країн-членів НАTO та положень Указу Президента України від 24.09.2015 № 555/2015 «Про нову редакцію Воєнної доктрини України» [35]. Відповідно до положень Указу Президента України від 24.09.2015 № 555/2015 «Про нову редакцію Воєнної доктрини України» [50], 3 метою пріоритетного розвитку військової медицини, виникла необхідність створити ефективну систему медичного забезпечення військ, шляхом проведення організаційноструктурних перетворень у медичній службі, 3 урахуванням інтеграції системи медичного забезпечення в загальнодержавну систему 03 $[24,34,59]$. В Україні питання профілактики серцево-судинних захворювань (ССЗ) набуло державного підходу: Наказом МОЗ України від 13.06.2016 № 564 затверджено Уніфікований клінічний протокол медичної допомоги (УКПМД) та Клінічна настанова (КН) «Профілактика серцево-судинних захворювань» [54, 67] та Урядом схвалено Концепцію розвитку системи громадського здоров'я як основи профілактичної медицини, що втілює основні системні заходи у сфері 03 [52]. Проте, в ЗС України стан медикотехнологічного незадовільний стандартизованого [35] i не існує профілактики хвороб системи кровообігу (ХСК) у військовослужбовців. Як зазначає О. Г. Шекера [71], на сьогодні система військової 03, яка функціонує в ЗС України, спрямована, головним чином, на надання медичної допомоги хворій людині і практично не виконує таку функцію як, власне, охорона здоров'я. Булах 0. Ю. $з$ співав. $[1,15]$ наголошують, що на сучасному етапі профілактична робота медичної служби військової ланки $є$ вкрай недостатньою, вона практично зруйнована, що впливає на рівень захворюваності військовослужбовців. Отже, враховуючи етап реформування ЗС України, актуальним $\epsilon$ створення на основі використання УКПМД «Профілактика серцевосудинних захворювань» [67], з урахуванням особливостей організації надання допомоги у військах та військових медичних закладах, галузевого клінічного протоколу, як одного 3 головних елементів функціональноорганізаційної моделі профілактики ХСК у військовослужбовців.

Сучасна система профілактичної медичної допомоги військовослужбовцям ЗС України [75] наведена на рис. 1.

На сьогоднішній день профілактика захворювань та чинників їх ризику у військовослужбовців здійснюється 32 військово-медичними закладами Міністерства оборони (МО) України, їх структурними підрозділами. Основний обсяг профілактичної роботи проводиться на рівні первинної ланки лікарями загальної практики-сімейної медицини (3П-СМ) [40].

Основою лікувально-профілактичних заходів у військовослужбовців ЗС України на сучасному етапі $\epsilon$ диспансеризація, метою якої $€$ раннє та активне виявлення захворювань, недопущення їх загострень, ускладнень та прогресування; найбільш важливими складовими диспансеризації $\epsilon$ : медичний огляд 3 проведенням визначеного обсягу лабораторних та інструментальних обстежень; додаткове обстеження осіб, які цього потребують; виявлення осіб 3 факторами ризику (ФР), що спричиняють виникнення та розвиток захворювань; своєчасне виявлення захворювань; розробку та проведення комплексу необхідних медичних та соціальних заходів, динамічного спостереження за станом здоров'я [47, 75]. Крім того, медичний контроль за станом здоров'я військових фахівців включає медичне обстеження й огляд військово-лікарською комісією [49] перед призначенням на посаду; повсякденне медичне спостереження за військовослужбовцями підрозділів і частин у процесі виконання службових обов'язків [45, 47]. В своїй практичній діяльності лікарі первинної військової медичної допомоги щодо контролю за станом здоров'я військовослужбовців керуються наступними нормативними документами:

1. Наказ МО України № 402 від 14.08.2008 (зі змінами) [49]. 
2. Наказ Директора департаменту 03 МO України № 113 від 12.12.2006 «Про затвердження Методики диспансерного динамічного нагляду при основних захворюваннях та аналізу диспансеризації військовослужбовців Збройних Сил України» [47].

3. Наказ № 178 від 21.03.2012 «Про затвердження Інструкції про порядок проведення диспансеризації військовослужбовців Державної спеціальної служби транспорту» [45].

4. Наказ Начальника Генерального штабу - Головнокомандувача 3С України № 391 від 04.11.2017 «Про затвердження Інструкції 3 диспансеризації військовослужбовців Збройних Сил України на мирний час" [40].

\section{СИСТЕМА МЕДИЧНОГО ЗАБЕЗПЕЧЕННЯ ЗС УКРАЇНИ}

\section{Профілактична медична допомога}

\begin{tabular}{|c|c|c|c|c|}
\hline Розроблен- & $\begin{array}{c}\text { Первинна } \\
\text { профілактична } \\
\text { медична допомога }\end{array}$ & $\begin{array}{c}\text { Вториина } \\
\text { профілактична } \\
\text { медична }\end{array}$ & $\begin{array}{c}\text { Третинна } \\
\text { профілактична } \\
\text { медична допомога }\end{array}$ & \multirow{3}{*}{$\begin{array}{c}\text { Наукові } \\
\text { досліджен- } \\
\text { ня. } \\
\text { створення } \\
\text { на їхній } \\
\text { основі } \\
\text { теоретичної } \\
\text { бази } \\
\text { системи } \\
\text { медичного } \\
\text { забезпечен- } \\
\text { ня 3С } \\
\text { України }\end{array}$} \\
\hline \multirow[t]{2}{*}{$\begin{array}{c}\text { і тактики } \\
\text { заходів } \\
\text { профілак- } \\
\text { тичної } \\
\text { медицини в } \\
\text { інтересах } \\
\text { збереження } \\
\text { здоров'я } \\
\text { всіх } \\
\text { категорій } \\
\text { військово- } \\
\text { службовиів } \\
\text { ЗС України }\end{array}$} &  & 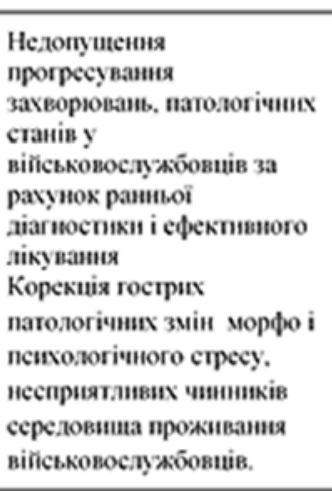 & 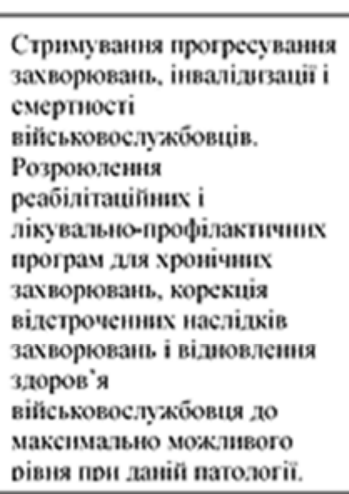 & \\
\hline & & & & \\
\hline & СОЦАА & -ГІГІЄНІЧНИЙ & ІТОРИНГ & \\
\hline
\end{tabular}

\section{ЗАБЕЗПЕЧЕННЯ ЗБЕРЕЖЕННЯ ЗДОРОВ'Я ВІЙСЬКОВОСЛУЖБОВЦІВ}

Рисунок 1. Сучасна система профілактичної медичної допомоги військовослужбовцям 3С України (згідно О. Г. Шекери, П. М. Яблонського, 2013).

На жаль, на сьогоднішній день керівні документи МО України щодо диспансеризації військовослужбовців не враховують: основні положення УКПМД «Профілактика серцевосудинних захворювань» [67], які передбачають в залежності від наявних ФР серцево-судинних захворювань (СС3) стратифікацію індивідуального ризику можливого настання серцево-судинних подій, а отже розробку індивідуалізованої лікувально-профілактичної програми залежно від визначеного ризику; використання відносної шкали SCORE для всіх військовослужбовців до 40 років; необхідність моніторингу ФР ССЗ під час поглиблених щорічних медичних оглядах; проведення профілактичного консультування всім, без виключення, пацієнтам; готовність пацієнта до змін моделі поведінки; проведення скринінгу коморбідних тривожнодепресивних розладів у військовослужбовців, особливо у військовослужбовців-учасників бойових дій [65].

Крім того, не регламентовано проведення виявлення ФР ССЗ призовникам на рівні військових комісаріатів та не визначено роль і місце цивільних закладів охорони здоров'я та закладів освіти, громадських і волонтерських організацій в реалізації профілактики ССЗ в період до призову в лави 3С України. 
Лікар загальної практики має можливість коригувати ФР у пацієнтів за допомогою не медикаментозних та медикаментозних втручань [30, 55]. Однак, як зазначають дослідники [21, 23, 25, 55, 56, 57, 61], цивільні лікарі первинної медичної допомоги скептично налаштовані щодо проведення профілактичних заходів, адже вважають, що результати профілактики незначні і не виправдовують затрачених зусиль, віддаючи перевагу лікувальнодіагностичній роботі. Так, за даними Гречишкіної Н. В., Грузєвої Т. С. [21], значна частина фахівців первинної медичної допомоги не має достатніх знань щодо профілактики основних неінфекційних хвороб та не докладає зусиль щодо консультації 3 питань корекції поведінкових ФР. В військовій ланці дане питання не досліджувалось. Крім того, надання якісних профілактичних послуг і ефективність їх впровадження в практику фахівцями первинної медичної допомоги залежить від рівня їх знань і умінь, що досягається шляхом безперервного професійного розвитку $[4,16,19,22,32,33,36$, 74]. Проте, на сьогоднішній день додипломна та післядипломна підготовка лікарів загальної практики у вищих медичних навчальних закладах України, передбачає розгляд профілактичних заходів в межах окремих нозологічних форм і у переважній більшості навчальних курсів програми інтернатури профілактична робота не висвітлена взагалі або представлена з позиції лікувальної парадигми охорони та зміцнення здоров'я [38, 39, 42, 58]. Враховуючи те, що Державна програма розвитку Збройних Сил України на період до 2020 року» [51], «Концепція Програми розвитку системи медичного забезпечення Збройних Сил України на період до 2020 року» [46] передбачають удосконалення системи підготовки та перепідготовки медичного персоналу для потреб 3С України, в учбову програму Української військово-медичної академії введено навчальну дисципліну «Доказова медицина. Підтримання здоров'я / профілактика» та розроблено відповідне навчально-методичне забезпечення [62]. Метою даної навчальної програми $\epsilon$ підготовки висококваліфікованих фахівців 3 достатнім обсягом теоретичних знань щодо принципів доказової медицини та практичних навичок пошуку, отримання, інтерпретації, критичної оцінки та використання в практичній діяльності науково доведеної інформації щодо доказової профілактики та сучасних аспектів доказового скринінгу, використання лікарських засобів, методів лікування, діагностики, які необхідні для підвищення якості медичної допомоги військовослужбовцям, підвищення рівня їх здоров'я та боєздатності і оптимізації діяльності системи охорони здоров'я на регіональному рівні в цілому.

В сучасних КН щодо профілактики ССЗ [54], УКПМД «Профілактика серцево-судинних захворювань» [67], в рекомендаціях Європейського товариства 3 гіпертензії i Європейського товариства кардіологів ESH/ESC [80], які грунтуються на результатах клініко-епідеміологічних досліджень, проведених на засадах доказової медицини, зроблено акцент на активному залученні медичних сестер до моніторингу корекції основних ФР та виконання рекомендацій лікаря щодо режиму прийому медикаментів та містяться принципово нові розділи, які рекомендують активну участь медичних сестер в підвищенні ефективності лікування артеріальної гіпертензії (АГ). Оскільки в літературних джерелах були відсутні відомості щодо участі молодших спеціалістів 3 медичною освітою (МСМО) військової первинної медичної допомоги 3С України в відповідних профілактичних програмах, колективом кафедри військової 3П-СМ було проведено дослідження щодо участі МСМО в профілактичних програмах та запроваджено цикл тематичної підготовки з цього питання 3 відповідним навчально-методичним забезпеченням [63].

На сучасному етапі доведена ефективність запровадження Шкіл здоров'я для пацієнта, зокрема при АГ, як сучасних технологій формування здорового способу життя ЗСЖ та вторинної профілактики АГ в первинній ланці 03 [13, 26, 43, 76], що регламентується УКПМД «Артеріальна гіпертензія» (Наказ МО3 від 24.05.2012 № 384) [70], а також Уніфікованим галузевим клінічним протоколом медичної допомоги (першої лікарської, кваліфікованої, спеціалізованої та невідкладної) (УГКПМд) «Артеріальна гіпертензія» [66]. Запровадження стратегї̈ формування ЗСЖ та стратегія високого ризику в первинній ланці 03 нададуть можливість за незначних фінансових видатків знизити через 5-10 років смертність від ХСК на 40-50 \%. Як приклад, у Запорізькому регіоні за 2 роки смертність від ХСК знизилася на 16 \%, від ускладнень АГ - на 
$28 \%$ за допомогою впровадження Шкіл здоров'я [29]. Але в УКПМД «Артеріальна гіпертензія» [66], УГКПМД «Артеріальна гіпертензія» [70] не розглядається питання організації Школи для пацієнта у разі коморбідних тривожних та депресивних розладів. Проте, відомо, що враховуючи протекторний вплив освіченості на симптоми тривоги, ефективною, як профілактика, може бути психоосвіта військовослужбовців щодо посттравматичного стресового розладу, навчання засобам психологічної амортизації та опрацювання надмірних переживань $[9,27$, 68, 69]. 3 урахуванням необхідності удосконалення технологій підвищення поінформованості військовослужбовців щодо лікування та профілактики захворювань. була розроблена та впроваджена в роботу клініки амбулаторної допомоги програма

\section{Висновки}

Узагальнення сучасних наукових даних щодо організації профілактики серцево-судинних захворювань у військовослужбовців на сучасному етапі виявив низку невирішених питань, а саме:

1. Найважливішим питанням залишається необхідність створення галузевого клінічного протоколу щодо профілактики серцево-судинних захворювань у військовослужбовців із метою стандартизованого підходу.

\section{Література}

1. Актуальні питання реформування системи медичного забезпечення Збройних Сил України на сучасному етапі / Булах О. Ю. та ін. Проблеми військової охорони здоров'я: збірник наукових праць Укр. військ.-мед. акад. Київ, 2012. Вип. 33. С. 26-32.

2 Актуальні питання стандартизації медичного забезпечення збройних сил України / Бадюк М. I., Середа I. К., Микита О. О., Жупан Б. Б. Украӥна. Здоров'я нації. 2016. № 4/1. С. 41.

3 Аналіз деяких напрямків наукових досліджень 3 питань організації медичного забезпечення Збройних сил України / Власенко О. М., Галушка А. М., Булах О. Ю., Стриженко В. І. Сучасні аспекти військової медицини: збірник наукових праць НВМКЦ «ГВКГ». Київ, 2016. Вип. 23. С. 3-12.

4. Аналіз проблемних питань існуючої системи підготовки кадрів для первинної ланки охорони здоров'я (літературний огляд) / Вороненко Ю. В., Шекера О. Г., Медведовська Н. В., Краснов В. В. Сімейна медицина. 2014. № 3 (53). С. 35-41.

5. Бадюк М. I. Організація медичного забезпечення військ: підруч. для студ. вищ. мед. закл. освіти України III-1V рівнів акредитації / за ред. проф. Паська В. В. Київ: «МП Леся», 2005. 430 с.
Національного

військово-медичного клінічного центру «ГВКГ» “Школи здоров'я для хворих на артеріальну гіпертензію військовослужбовців 3 коморбідними тривожними і депресивними розладами» [44, 62]. Проте потребує уваги те, що відповідні «Школи здоров'я» повинні бути організовані у військових закладах 03 для залучення різних категорій військовослужбовців до профілактики ССЗ шляхом участі в їх роботі.

Таким чином, враховуючи стратегічний курс ЗС України на євроатлантичну інтеграцію та сумісність забезпечення 3С України 3 медичним забезпечення країн-членів НАТО, де найважливіше місце займають превентивні заходи, постає питання про необхідність подальшого удосконалення існуючої системи профілактики ССЗ у військовослужбовців.

2. Не регламентовано проведення виявлення факторів ризику серцевосудинних захворювань призовників на рівні військових комісаріатів.

3. Не визначено роль і місце цивільних закладів охорони здоров'я та закладів освіти, громадських і волонтерських організацій в реалізації профілактики серцево-судинних захворювань у період до призову до лав ЗС України.

6. Бадюк M. I. Організація медичного забезпечення військ: підруч. для студ. вищ. мед. (фармац.) навч. закл. України / М. І. Бадюк, В. В. Солярик, В. П. Токарчук; за ред. М. І. Бадюка. Київ: «МП Леся», 2014. 492 с.

7. Бадюк М. I. Основні засади формування нормативної бази діяльності медичної служби Збройних Сил України. Військова медицина Украӥни. 2007. T. 7. № 1-2. С. 5-9.

8. Бадюк М. I., Микита О. О., Губар А. М. Обгрунтування моделі стандартизації медичного забезпечення Збройних Сил України та оцінка їі ефективності Wschodnioeuropejskie Czasopismo Naukowe (East European Scientific Journal). 2016. № 7. C. 37-46.

9. Безшейко В. Г. Ефективність короткотривалих психологічних інтервенцій при посттравматичному стресовому розладі. Архів ncuxiampiï. 2016. T. 22. № 1 (84). C. 12-16.

10. Бібік Т. А., Мороз Г. З., Ткачук І. М. Організація медичної допомоги військовослужбовцям, хворим на артеріальну гіпертензію, в амбулаторних умовах на засадах доказової медицини: навч. посіб. для лікарів-курсантів, лікарів-слухачів закл. 
післядиплом. освіти / Укр. військ.-мед. акад., Голов. військ.-мед. клініч. центр "ГВКГ". Київ, 2011. 95 с.

11. Білий В. Я., Жаховський В. О., Лівінський В. Г. Місце та роль Воєнно-медичної доктрини України у формуванні системи медичного забезпечення військ і цивільного населення у воєнний час. Наука і оборона. 2015. № 1. С. 9-14.

12. Білий В. Я., Пасько В. В., Сохін О. О. Військовомедична доктрина України. Наука і оборона. 2000. № 4. С. 18-23.

13. Бойко Т. Я. Роль первинної ланки у профілактиці артеріальної гіпертензії серед дорослого населення. Здобутки клінічної $i$ експериментальної медицини: матеріали Всеукраїнської науково-практичної конференції «Актуальні питання діагностики, лікування, раціональної фармакотерапії, диспансеризації та реабілітації в практиці сімейного лікаря» 2016. № 2. C. 111.

14. Булах О. Ю. Нормативно-правова база організації медичного забезпечення Збройних Сил України в сучасних умовах та основні напрямки їі удосконалення. Проблеми військової охорони здоров'я: збірник наукових праць Укр. військ.-мед. академії. Київ, 2013. Вип. 40. С. 12-21.

15. Булах О. Ю., Халік С. В., Лопін Є. Б. Аналіз співвідношення окремих статистичних показників діяльності медичної служби військової та госпітальної ланок Збройних Сил України. Сучасні аспекти військової медицини: збірник наукових праць НВМКЦ «ГВКГ». Київ, 2013. Вип. 20. С. 3-11.

16. Вежновець Т. А., Парій В. Д. Вплив віку, досвіду роботи та особистісних рис медичного персоналу на якість надання медичної допомоги. Україна. Здоров'я нації. 2015. № 4 (36). С. 81-87.

17. Вивчення динаміки та структури захворюваності на хвороби органів системи кровообігу військовослужбовців Збройних Сил України / Чорна Л. М., Карпенко О. І., Савицький В. Л., Устінова Л. А. Проблеми військової охорони здоров'я: збірник наукових праць Укр. військ.-мед. академії. Київ, 2015. Вип. 43. С. 118-126.

18. Вороненко Ю. В., Горачук В. В. Методичні підходи до впровадження стандартизації організаційних технологій у систему управління якістю медичної допомоги. Український медичний часопис. 2012. № 5. С. 108-110.

19. Вороненко Ю. В., Шекера О. Г., Медведовська Н. В. Проблемні питання системи підготовки кадрів для первинної ланки охорони здоров'я та шляхи їх вирішення. Здоров'я суспільства. 2016. № 3-4. С. 78-80.

20. Горачук В. В. Управління якістю медичної допомоги в закладі охорони здоров'я: монографія. Вінниця: ПП Балюк І.Б., 2012. С. 18-21.

21. Гречишкіна Н. В., Грузєва Т. С. Визначення обізнаності та ставлення лікарів первинної ланки щодо профілактики неінфекційних захворювань. Семейная медищина. 2015. № 6 (62). С. 22-24.

22. Грузєва Т. С., Пузанова О. Г. Інформаційне забезпечення фахівців первинної ланки охорони здоров'я з питань доказової профілактики. Україна. Здоров'я нації. 2015. № 2. С. 91-95.

23. Дроздова Л. Ю., Марцевич С. Ю., Воронина В. П. Одновременная оценка распространенности и эффективности коррекции факторов риска сердечно-сосудистых заболеваний среди врачей и их знания современных клинических рекомендаций. Результаты проекта «Здоровье и образование врача». Рациональная фармакотерапия в кардиологии. 2011. Вип. 7 № 2. С. 137-144.

24. Жаховський В. О., Булах О. Ю., Стриженко В. І. Система управління медичним забезпеченням $3 \mathrm{C}$ України: потреба в удосконаленні. Наука і оборона. 2013. № 1. С. 23-27.

25. Зюков О. Л., Грузєва Т. С. Попередній досвід вивчення знань, ставлення та навичок медичних працівників первинної ланки 3 питань профілактики хронічних неінфекційних захворювань. Главный врач. 2014. № 6. С. 19-23.

26. Калинина А. М. Школа здоровья для больных как фактор повышения эффективности контроля артериальной гипертонии. Трудный пащиент. 2006. № 8. C. 21-23.

27. Кожина А. М., Гайчук Л. М., Шикова В. В. Ефективність психоосвітніх програм в наданні допомоги особам, що перенесли екстремальні події/ Украӥнський вісник психоневрології. 2015. Том 23. № 2 (83). С.109.

28. Концептуальні засади формування сучасної системи лікувально-евакуаційного забезпечення військ (сил) у контексті формування нового обрису Збройних Сил України / Верба А. В. та ін. Військова медицина України. 2016. Т. 16. № 2. С. 5-14.

29. Лашкул 3. В. Концептуальні підходи до профілактики артеріальної гіпертензії в умовах реформування охорони здоров'я. Український медичний часопис. 2014. № 6. С. 149-151.

30. Лашкул 3. В. Роль врача общей практики в профилактике сердечно -сосудистых заболеваний. Сучасні медичні технології. Український науковопрактичний журнал. 2010. № 3. С. 123-126.

31. Майданюк В. П., Завроцький О. І. Роль і значення системи військової охорони здоров'я в збройних силах України. Сучасні аспекти військової медицини: збірник наукових праць НВМКЦ «ГВКГ». К., 2014. Вип. 21. С. 49-57.

32. Матюха Л. Ф. Підходи до оцінки ефективності лікарської практики з надання первинної медичної допомоги. Україна. Здоров'я нації. 2017. № 2 (43). С. $140-142$.

33. Медико-соціологічне дослідження поінформованості лікарів первинної ланки надання медичної допомоги щодо діагностики, лікування та профілактики артеріальної гіпертензії на засадах доказової медицини. / Ткачук І. М., Захарчук Л. М., Міхальцова Л. В., Владика Л. Ф. Сучасні аспекти військової медицини: збірник наукових праць ГВМКЦ «ГВКГ» МО України. Київ, 2010. Вип 17. С. 123-130.

34. Медичне забезпечення антитерористичної операції: Воєнно-медична доктрина України як 
інструмент формування єдиного медичного простору / Жаховський В. О., Лівінський В. Г., Кудренко М. В., Мельник І. П. Україна. Здоров'я нації. 2015. № 1. С. 7-15.

35. Микита 0. О. Наукове обгрутування стандартизації медичного забезпечення Збройних Сил України в умовах антитерористичної операції: автореф. дис. на здобуття наук. ступеня канд. мед. наук: спец. 14.02.03. «Соціальна медицина» / Укр. військ.-мед. акад. Міністерства оборони України. К., 2016. 28 с.

36. Міжсекторальна взаємодія освіти, науки та практики як запорука ефективної підготовки кадрів / Вороненко Ю. В. та ін. Сімейна медицина. 2014. № 4. C. 10-16.

37. Міністерство оборони України. Проектний офіс реформ: веб-сайт. URL: https://defensereforms.in.ua

38. М03 України. Навчальний план та уніфікована програма циклу спеціалізації за фахом «Загальна практика-сімейна медицина». Київ, 2012. $61 \mathrm{c}$.

39. М03 України. Типовий навчальний план i програма спеціалізації (інтернатури) випускників вищих медичних закладів освіти III-IV рівнів акредитації за спеціальністю «Загальна практикасімейна медицина», Київ, 2011. 80 с.

40. Наказ Начальника Генерального штабу Головнокомандувача Збройних Сил України № 391 від 04.11.2017 «Про затвердження Інструкції 3 диспансеризації військовослужбовців Збройних Сил України на мирний час"

41. Обгрунтування основних вимог до системи медичного забезпечення Збройних Сил України в сучасних умовах / Верба А. В., Галушка А. М., Булах О. Ю., Стриженко В. І. Військова медицина Украӥни. 2016. T. 16. № 3. С. 5-13.

42. Організація навчального процесу лікарівінтернів за фахом “Загальна практика-сімейна медицина” на базі стажування: навч.-метод. посіб. для керівників заочного періоду навчання / Кривенко В. I. та ін. Запоріжжя, 2014. 65 с.

43. Організація Шкіл здоров'я для пацієнтів 3 гіпертонічною хворобою в первинній ланці охорони здоров'я: методичні рекомендації МОЗ України / Лашкул 3. В., Посний В. С., Авраменко В. С., Одринський В. А. Київ, 2012. 27 с.

44. Практичні аспекти організації «Школи здоров'я для хворих на артеріальну гіпертензію військовослужбовців з коморбідними тривожними та депресивними розладами» в умовах денного стаціонару: методичні рекомендації / Мороз Г. 3., Бібік Т. А., Партасюк Н. Ю., Ткачук І. М. Київ: РВВ УВМА, 2011. 27 c.

45. Про затвердження Інструкції про порядок проведення диспансеризації військовослужбовців Державної спеціальної служби транспорту: наказ № 178 від 21 березня 2012. URL: http://zakon2.rada.gov.ua/laws/show/z0512-12

46. Про затвердження Концепції програми розвитку системи медичного забезпечення
Збройних Сил України на період до 2020 року: наказ Міністерства Оборони України від 26 липня 2017 p. № $389 . \quad$ URL: http://www.mil.gov.ua/content/mou orders/389 nm 2017.pdf

47. Про затвердження Методики диспансерного динамічного нагляду при основних захворюваннях та аналізу диспансеризації військовослужбовців Збройних Сил України»: наказ Директора департаменту охорони здоров'я МО України від 12 грудня 2006 р. № 113.85 с.

48. Про затвердження плану заходів з реалізації Концепції реформи фінансування системи охорони здоров'я на період до 2020 року: затверджено розпорядженням Кабінету Міністрів України від 15.11.2017 № 821-p URL: https://www.kmu.gov.ua/ua/npas/250432586

49. Про затвердження Положення про військово-лікарську експертизу в Збройних Силах України: Наказ Міністерства Оборони України від 14.08.2008 № 402. Остання редакція: 30.01.2018. URL: http://zakon0.rada.gov.ua/laws/show/z1109-08

50. Про рішення Ради національної безпеки i оборони України від 2 вересня 2015 року «Про нову редакцію Воєнної доктрини України»: Указ Президента України від 24 жовтня 2015 р. № 555 URL:

http://www.president.gov.ua/documents/555201519443

51. Про рішення Ради національної безпеки і оборони України від 29 грудня 2016 року «Про Державну програму розвитку Збройних Сил України на період до 2020 року»: Указ Президента України від 22.03.2017 № 73. URL: http://www.president.gov.ua/documents/732017$\underline{21498}$

52. Про схвалення Концепції розвитку системи громадського здоров'я: розпорядження Кабінету Міністрів України № 1002-р від 30 листопада 2016 p. URL:

https://www.kmu.gov.ua/ua/npas/249618799

53. Професійна надійність військовослужбовців в умовах переходу на контрактний принцип комплектування Збройних Сил України / Бібік Т. А., Ткачук I. М., Устименко О. В., Устименко В. В. Проблеми військової охорони здоров'я: збірник наукових праць Укр. військ.-мед. академії. Київ, 2011. Вип. 30. С. 22-29.

54. Профілактика серцево-судинних захворювань: адаптована клінічна настанова, заснована на доказах / Державний експертний центр Міністерства охорони здоров'я України. Асоціація кардіологів України. Українська асоціація сімейної медицини. Київ, 2016. 127 с. URL: http://mtd.dec.gov.ua/images/dodatki/2016_564_PSS Z/2016_564_AKN_PSSZ.pdf

55. Профілактика серцево-судинних захворювань: роль сімейного лікаря / Росул М. М., Фейса С. В., Іваньо Н. В., Корабельщикова М. О. Україна. Здоров'я нації. 2015. № 1 (33). С. 178-182. 
56. Радченко Г. Д., Марцовенко І. М., Сіренко Ю. М. Профілактика серцево-судинних захворювань почни з себе. Результати анонімного опитування лікарів, які лікують пацієнтів 3 артеріальною гіпертензією. Украйнський кардіологічний журнал. 2011. № 4. C. 54-58.

57. Ринда Ф. П., Ситенко О. Р. До питання застосування профілактичних методів у практичній діяльності лікарів загальної практики сімейних лікарів. Україна. Здоров'я нації. 2017. № 4 (45). С. 68-72.

58. Ринда Ф.П., Шафранський В. В. Профілактична підготовка лікарів-інтернів за спеціальністю «Загальна практика - сімейна медицина». Україна. Здоров'я нації. 2017. № 1 (42). С. 151-162.

59. Система медичного забезпечення військ (сил) - складова загальнодержавної політики охорони здоров'я громадян України / Савицький В. Л., Власенко О. М., Стриженко В. І., Булах О. Ю. Наука і оборона. 2014. № 2. С. 27-33.

60. Степаненко А. В., Сміянов В. А. Управління якістю медичної допомоги в закладі охорони здоров'я. Східноєвропейський журнал громадського здоров'я. 2012. № 2-3. С. 64-67.

61. Стратегія розвитку профілактики в охороні здоров'я України / Сердюк А. М., Кундієв Ю. І., Нагорна А. М., Широбоков В. П. Журнал НАМН України. 2012. Т. 18. № 3. С. 358-371.

62. Ткачук I. М. Профілактика серцево-судинних захворювань у військовослужбовців: електронний посібник для лікарів. Київ: ТОВ «Друкарня «Бізнесполіграф», 2018.91 с.

63. Ткачук I. М. Профілактика серцево-судинних захворювань у військовослужбовців: електронний посібник для молодших спеціалістів з медичною освітою. Київ: ТОВ «Друкарня «Бізнесполіграф», 2018. 26 c.

64. Ткачук I. М., Мороз Г. З. Здоров'я та профілактика серцево-судинних захворювань у військовослужбовців: інформаційний посібник для військовослужбовців. Київ: УВМА, 2017. 24 с

65. Ткачук I. М., Мороз Г. З. Розробка пропозицій щодо створення галузевого клінічного протоколу медичної допомоги «Профілактика серцевосудинних захворювань у військовослужбовців». Військова медицина України. 2017. № 2. Т.17. С. 20-24.

66. Уніфікований галузевий клінічний протокол медичної допомоги (першої лікарської, кваліфікованої, спеціалізованої та невідкладної) «Артеріальна гіпертензія» / ВМД Міністерства Оборони України. Київ: УВМА, 2014. 96 с.

67. Уніфікований клінічний протокол первинної, вторинної (спеціалізованої) та третинної (високоспеціалізованої) медичної допомоги "Профілактика серцево-судинних захворювань”: наказ МОЗ України від 13.06.2016 № 564 http://mtd.dec.gov.ua/index.php/uk/reiestrmtd/item/71-profilaktyka-sertsevosudynnykhzakhvoriuvan
68. Уніфікований клінічний протокол первинної, вторинної (спеціалізованої) та третинної (високоспеціалізованої) медичної допомоги «Депресія (легкий, помірний, тяжкий депресивні епізоди без соматичного синдрому або 3 соматичним синдромом, рекурентний депресивний розлад, дистимія»: наказ МОЗ України від 25.12.2014 № $1003 . \quad$ URL: http://mtd.dec.gov.ua/index.php/uk/reiestrmtd/item/12-depresiia

69. Уніфікований клінічний протокол первинної, вторинної (спеціалізованої) та третинної (високоспеціалізованої) медичної допомоги «Реакція на важкий стрес та розлади адаптації. Посттравматичний стресовий розлад»: наказ М03 України № 121 від 23 лютого 2016 р. URL: $\quad$ http://mtd.dec.gov.ua/index.php/uk/reiestr$\mathrm{mtd} /$ item/60-posttravmatychnyi-stresovyi-rozlad

70. Уніфікований клінічний протокол первинної, екстреної та вторинної (екстреної) медичної допомоги. «Артеріальна гіпертензія»: Наказ МО3 від 24.05.2012 № 384. URL: http://mtd.dec.gov.ua/imag es/dodatki/384_2012/384_2012ykpmd_ag.pdf

71. Шекера О. Г. Концептуальні положення щодо реформування медичного забезпечення Збройних Сил України. Здоров'я суспільства. 2015. № 1-2. С. 85-92.

72. Шекера О. Г. Підвищення взаємосумістності між медичним забезпеченням збройних сил України та НАТО. Здоров'я суспільства. 2016. Т. 5. № 3-4. C. 56-63.

73. Шекера О. Г. Стратегічний курс медичного забезпечення збройних сил країн НАТО. Вісник наукового інформаційно-аналітичного центру нАТО Прикарпатського національного університету імені Василя Стефаника. 2009. Вип. 2. C. $158-164$.

74. Шекера О. Г., Краснов В. В. Розроблення компетентнісної моделі лікаря загальної практики-сімейного лікаря. Сімейна медицина. 2013. № 6. C. 21-23.

75. Шекера О. Г., Яблонський П. М. Застосування оптимальної моделі диспансеризації військовослужбовців при плануванні профілактичної діяльності лікаря загальної практики - сімейної медицини. Сімейна медицина. 2013. № 1. С. $18-22$.

76. Школа здоров'я, як сучасна технологія вторинної профілактики артеріальної гіпертензії в первинній ланці охорони здоров'я: навчальнометодичний посібник / Лашкул 3. В., Посний В. С., Авраменко В. С., Одринський В. А. Київ, 2012. 49 с.

77. AJP 4.10 (B) Allied joint medical support doctrine. Brussels: Supreme Headquarters of Allied Powers in Europe, 2015. 170 p.

78. Allied Joint Publication-4.10(B). Allied Joint Doctrine for Medical Support. Edition B Version 1 with UK National elements. 2015. 280 p. URL: https://assets.publishing.service.gov.uk/government/ uploads/system/uploads/attachment_data/file/4571 42/20150824-AJP_4_10_med_spt_uk.pdf 
79. MC 326/3. NATO principles and policies of operational medical support. 2011. 27 p.

80. $2013 \mathrm{ESH} / \mathrm{ESC}$ Guidelines for the management of arterial hypertension. The Task Force for the management of arterial hypertension of the European

\section{References}

1. Bulakh, 0. Y. (2012). Aktualni pytannia reformuvannia systemy medychnoho zabezpechennia Zbroinykh Syl Ukrainy na suchasnomu etapi. Problemy viiskovoi okhorony zdorovia, 33, 26-32.

2. Badiuk, M. I., Sereda I. K., Mykyta, O. O., Zhupan B. B. (2016). Aktualni pytannia standartyzatsii medychnoho zabezpechennia zbroinykh syl Ukrainy. Ukraina. Zdorovia natsii, 4 (1), 41.

3. Vlasenko, O. M., Halushka, A. M., Bulakh, O. Yu., Stryzhenko, V. I. (2016). Analiz deiakykh napriamkiv naukovykh doslidzhen $\mathrm{z}$ pytan orhanizatsii medychnoho zabezpechennia Zbroinykh syl Ukrainy. Suchasni aspekty viiskovoi medytsyny, 23, 3-12.

4. Voronenko, Yu. V., Shekera, O. H., Medvedovska, N. V., Krasnov, V. V. (2014). Analiz problemnykh pytan isnuiuchoi systemy pidhotovky kadriv dlia pervynnoi lanky okhorony zdorovia (literaturnyi ohliad). Simeina medytsyna, 3 (53), 35-41.

5. Badiuk, M. I. (2005). Orhanizatsiia medychnoho zabezpechennia viisk: pidruch. dlia stud. vyshch. med. zakl. osvity Ukrainy III-1V rivniv akredytatsii / za red. prof. Paska V. V. Kyiv, 430.

6. Badiuk, M. I., Soliaryk, V. V., Tokarchuk, V. P. (2014). Orhanizatsiia medychnoho zabezpechennia viisk: pidruch. dlia stud. vyshch. med. (farmats.) navch. zakl. Ukrainy. Kyiv, 492.

7. Badiuk, M. I. (2007). Osnovni zasady formuvannia normatyvnoi bazy diialnosti medychnoi sluzhby Zbroinykh Syl Ukrainy. Viiskova medytsyna Ukrainy, 1-2, 5-9.

8. Badiuk, M. I., Mykyta, O. O., Hubar, A. M. (2016). Obgruntuvannia modeli standartyzatsii medychnoho zabezpechennia Zbroinykh Syl Ukrainy ta otsinka yii efektyvnosti. Wschodnioeuropejskie Czasopismo Naukowe (East European Scientific Journal), 7, 37-46.

9. Bezsheiko, V. H. (2016). Efektyvnist korotkotryvalykh psykholohichnykh interventsii pry posttravmatychnomu stresovomu rozladi. Arkhiv psykhiatrii, 1 (84), 12-16.

10. Bibik, T. A., Moroz, H. Z., Tkachuk, I. M. (2011). Orhanizatsia medychnoi dopomohy viiskovosluzhbovtsiam, khvorym na arterialnu hipertenziiu, $\mathrm{v}$ ambulatornykh umovakh na zasadakh dokazovoi medytsyny: navch. posib. dlia likarivkursantiv, likariv-slukhachiv zakl. pisliadyplom. osvity. Kyiv, 95.

11. Bilyi. V. Ya., Zhakhovskyi, V. O., Livinskyi, V. H. (2015). Mistse ta rol Voienno-medychnoi doktryny Ukrainy $\mathrm{u}$ formuvanni systemy medychnoho zabezpechennia viisk i tsyvilnoho naselennia $\mathrm{u}$ voiennyi chas. Nauka i oborona, 1, 9-14.

12. Bilyi, V. Ya., Pasko, V. V., Sokhin. O. O. (2000). Viiskovo-medychna doktryna Ukrainy. Nauka $i$ oborona, 4, 18-23.
Society of Hypertension (ESH) and of the European Society of Cardiology (ESC) / Mancia G. et al. European Heart Journal. 2013. Volume 34. Issue 28. P. 21592219. https://doi.org/10.1093/eurheartj/eht151

13. Boiko, T. Ya. (2016). Rol pervynnoi lanky u profilaktytsi arterialnoi hipertenzii sered dorosloho naselennia. Zdobutky klinichnoi i eksperymentalnoi medytsyny, 2, 111.

14. Bulakh, O. Yu. (2013). Normatyvno-pravova baza orhanizatsii medychnoho zabezpechennia Zbroinykh Syl Ukrainy $\mathrm{v}$ suchasnykh umovakh ta osnovni napriamky yii udoskonalennia. Problemy viiskovoi okhorony zdorovia, 40, 12-21.

15. Bulakh, O. Yu., Khalik, S. V., Lopin, Ye. B. (2013). Analiz spivvidnoshennia okremykh statystychnykh pokaznykiv diialnosti medychnoi sluzhby viiskovoi ta hospitalnoi lanok Zbroinykh Syl Ukrainy. Suchasni aspekty viiskovoi medytsyny, 20, 3-11.

16.Vezhnovets, T. A., Parii, V. D. (2015). Vplyv viku, dosvidu roboty ta osobystisnykh rys medychnoho personalu na yakist nadannia medychnoi dopomohy. Ukraina. Zdorovia natsii, 4 (36), 81-87.

17.Chorna, L. M., Karpenko, O. I., Savytskyi, V. L., Ustinova, L. A. (2015). Vyvchennia dynamiky ta struktury zakhvoriuvanosti na khvoroby orhaniv systemy krovoobihu viiskovosluzhbovtsiv Zbroinykh Syl Ukrainy. Problemy viiskovoi okhorony zdorovia, 43, 118-126.

18.Voronenko, Yu. V., Horachuk, V. V. (2012). Metodychni pidkhody do vprovadzhennia standartyzatsii orhanizatsiinykh tekhnolohii u systemu upravlinnia yakistiu medychnoi dopomohy. Ukrainskyi medychnyi chasopys, 5, 108-110.

19.Voronenko, Yu. V., Shekera, O. H., Medvedovska, N. V. (2016). Problemni pytannia systemy pidhotovky kadriv dlia pervynnoi lanky okhorony zdorovia ta shliakhy yikh vyrishennia. Zdorovia suspilstva, 3-4, 78-80.

20.Horachuk, V. V. (2012). Upravlinnia yakistiu medychnoi dopomohy $\mathrm{v}$ zakladi okhorony zdorovia: monohrafiia. Vinnytsia.

21. Hrechyshkina, N. V., Hruzieva, T. S. (2015). Vyznachennia obiznanosti ta stavlennia likariv pervynnoi lanky shchodo profilaktyky neinfektsiinykh zakhvoriuvan. Semeinaia medytsyna, 6 (62), 22-24.

22. Hruzieva, T. S., Puzanova, O. H. (2015). Informatsiine zabezpechennia fakhivtsiv pervynnoi lanky okhorony zdorovia $\mathrm{z}$ pytan dokazovoi profilaktyky. Ukraina. Zdorovia natsii, 2, 91-95.

23. Drozdova, L. Yu., Martsevych, S. Yu., Voronyna, V. P. (2011). Odnovremennaia otsenka rasprostranennosty y effektyvnosty korrektsyy faktorov ryska serdechno-sosudystikh zabolevanyi sredy vrachei y ykh znanyia sovremennykh klynycheskykh rekomendatsyi. Rezultati proekta «Zdorove y obrazovanye vracha». Ratsyonalnaia farmakoterapyia $v$ kardyolohyy, 7 (2), 137-144.

24.Zhakhovskyi, V. O., Bulakh, O. Yu., Stryzhenko, V. I. (2013). Systema upravlinnia medychnym 
zabezpechenniam ZS Ukrainy: potreba v udoskonalenni. Nauka i oborona, 1, 23-27.

25.Ziukov, O. L., Hruzieva, T. S. (2014). Poperednii dosvid vyvchennia znan, stavlennia ta navychok medychnykh pratsivnykiv pervynnoi lanky $\mathrm{z}$ pytan profilaktyky khronichnykh neinfektsiinykh zakhvoriuvan. Hlavnyi vrach, 6, 19-23.

26. Kalynyna, A. M. (2006). Shkola zdorovia dlia bolnykh kak faktor povyshenyia effektyvnosty kontrolia arteryalnoi hypertonyy. Trudnyi patsyent, 8, 21-23.

27. Kozhyna, A. M., Haichuk, L. M., Shykova, V. V. (2015). Efektyvnist psykhoosvitnikh prohram v nadanni dopomohy osobam, shcho perenesly ekstremalni podii. Ukrainskyi visnyk psykhonevrolohii, 2 (83), 109.

28.Verba, A. V. (Eds.). (2016). Kontseptualni zasady formuvannia suchasnoi systemy likuvalnoevakuatsiinoho zabezpechennia viisk (syl) u konteksti formuvannia novoho obrysu Zbroinykh Syl Ukrainy. Viiskova medytsyna Ukrainy, 2, 5-14.

29. Lashkul, Z. V. (2014). Kontseptualni pidkhody do profilaktyky arterialnoi hipertenzii $\mathrm{V}$ umovakh reformuvannia okhorony zdorovia. Ukrainskyi medychnyi chasopy, 6, 149-151.

30. Lashkul, Z. V. (2010). Rol vracha obshchei praktyky V profylaktyke serdechno-sosudystykh zabolevanyi. Suchasni medychni tekhnolohii. Ukrainskyi naukovo-praktychnyi zhurnal, 3, 123-126.

31. Maidaniuk, V. P., Zavrotskyi, O. I. (2014). Rol i znachennia systemy viiskovoi okhorony zdorovia $\mathrm{v}$ zbroinykh sylakh Ukrainy. Suchasni aspekty viiskovoi medytsyny, 21, 49-57.

32. Matiukha, L. F. (2017). Pidkhody do otsinky efektyvnosti likarskoi praktyky z nadannia pervynnoi medychnoi dopomohy. Ukraina. Zdorovia natsii, 2 (43), 140-142.

33. Tkachuk, I. M., Zakharchuk, L. M., Mikhaltsova, L. V., Vladyka, L. F. (2010). Medyko-sotsiolohichne doslidzhennia poinformovanosti likariv pervynnoi lanky nadannia medychnoi dopomohy shchodo diahnostyky, likuvannia ta profilaktyky arterialnoi hipertenzii na zasadakh dokazovoi medytsyny. Suchasni aspekty viiskovoi medytsyny, 17, 123-130.

34. Zhakhovskyi, V. O., Livinskyi, V. H., Kudrenko, M. V., Melnyk. I. P. (2015). Medychne zabezpechennia antyterorystychnoi operatsii: Voienno-medychna doktryna Ukrainy yak instrument formuvannia yedynoho medychnoho prostoru. Ukraina. Zdorovia natsii, 1, 7-15.

35. Mykyta, 0. 0. (2016). Naukove obhrutuvannia standartyzatsii medychnoho zabezpechennia Zbroinykh Syl Ukrainy v umovakh antyterorystychnoi operatsii (doctoral dissertation), $28 \mathrm{p}$.

36. Voronenko, Yu. V. (Eds.). (2014). Mizhsektoralna vzaiemodiia osvity, nauky ta praktyky yak zaporuka efektyvnoi pidhotovky kadriv. Simeina medytsyna, 4, 10-16.

37. Ministerstvo oborony Ukrainy. Proektnyi ofis reform. Web site: https://defense-reforms.in.ua
38. MOZ Ukrainy. (2012) Navchalnyi plan ta unifikovana prohrama tsyklu spetsializatsii za fakhom «Zahalna praktyka-simeina medytsyna». $61 \mathrm{p}$.

39. MOZ Ukrainy. (2011). Typovyi navchalnyi plan i prohrama spetsializatsii (internatury) vypusknykiv vyshchykh medychnykh zakladiv osvity III-IV rivniv akredytatsii za spetsialnistiu «Zahalna praktykasimeina medytsyna». $80 \mathrm{p}$.

40.Pro zatverdzhennia Instruktsii z dyspanseryzatsii viiskovosluzhbovtsiv Zbroinykh Syl Ukrainy na myrnyi chas. (2017). Nakaz Nachalnyka Heneralnoho shtabu - Holovnokomanduvacha Zbroinykh Syl Ukrainy № 391 vid 04.11.2017.

41.Verba, A. V., Halushka, A. M., Bulakh, O. Yu., Stryzhenko, V. I. (2016) Obgruntuvannia osnovnykh vymoh do systemy medychnoho zabezpechennia Zbroinykh Syl Ukrainy v suchasnykh umovakh. Viiskova medytsyna Ukrainy, 3, 5-13.

42. Kryvenko, V. I. (2014). Orhanizatsiia navchalnoho protsesu likariv-interniv za fakhom Zahalna praktyka-simeina medytsyna na bazi stazhuvannia: navch.-metod. posib. dlia kerivnykiv zaochnoho periodu navchannia. Zaporizhzhia, 65 p.

43.Lashkul, Z. V., Posnyi, V. S., Avramenko, V. S., Odrynskyi, V. A. (2012). Orhanizatsiia Shkil zdorovia dlia patsiientiv $\mathrm{z}$ hipertonichnoiu khvoroboiu $\mathrm{V}$ pervynnii lantsi okhorony zdorovia: metodychni rekomendatsii MOZ Ukrainy. Kyiv, 27 p.

44.Moroz, H. Z., Bibik, T. A., Partasiuk, N. Yu., Tkachuk, I. M. (2011). Praktychni aspekty orhanizatsii «Shkoly zdorovia dlia khvorykh na arterialnu hipertenziiu viiskovosluzhbovtsiv $\mathrm{z}$ komorbidnymy tryvozhnymy ta depresyvnymy rozladamy» v umovakh dennoho statsionaru: metodychni rekomendatsii. Kyiv, $27 \mathrm{p}$.

45.Pro zatverdzhennia Instruktsii pro poriadok provedennia dyspanseryzatsii viiskovosluzhbovtsiv Derzhavnoi spetsialnoi sluzhby transport. (2012). Nakaz № 178 vid 21.03.2012. http://zakon2.rada.gov.ua/laws/show/z0512-12

46.Pro zatverdzhennia Kontseptsii prohramy rozvytku systemy medychnoho zabezpechennia Zbroinykh Syl Ukrainy na period do 2020 roku. (2017). Nakaz Ministerstva Oborony Ukrainy vid 26.07.2017. № 389 .

http://www.mil.gov.ua/content/mou_orders/389_nm _2017.pdf

47.Pro zatverdzhennia Metodyky dyspansernoho dynamichnoho nahliadu pry osnovnykh zakhvoriuvanniakh ta analizu dyspanseryzatsii viiskovosluzhbovtsiv Zbroinykh Syl Ukrainy». (2006). Nakaz Dyrektora departamentu okhorony zdorovia MO Ukrainy vid 12.12.2006 № 113.85 p.

48. Pro zatverdzhennia planu zakhodiv z realizatsii Kontseptsii reformy finansuvannia systemy okhorony zdorovia na period do 2020 roku. (2017). Zatverdzheno rozporiadzhenniam Kabinetu Ministriv Ukrainy vid 15.11.2017 № 821-r. : https://www.kmu.gov.ua/ua/npas/250432586

49.Pro zatverdzhennia Polozhennia pro viiskovolikarsku ekspertyzu v Zbroinykh Sylakh Ukrainy (2008). Nakaz Ministerstva Oborony Ukrainy vid 
14.08.2008

№

402.

http://zakon0.rada.gov.ua/laws/show/z1109-08

50. Pro novu redaktsiiu Voiennoi doktryny Ukrainy. (2015). Ukaz Prezydenta Ukrainy vid 24.10.2015 № 555.

http://www.president.gov.ua/documents/555201519443

51.Pro Derzhavnu prohramu rozvytku Zbroinykh Syl Ukrainy na period do 2020 roku. (2017). Ukaz Prezydenta Ukrainy vid 22.03.2017 № 73. http://www.president.gov.ua/documents/73201721498

52. Pro skhvalennia Kontseptsii rozvytku systemy hromadskoho zdorovia. (2016). Rozporiadzhennia Kabinetu Ministriv Ukrainy № 1002-r vid 30.11.2016. : https://www.kmu.gov.ua/ua/npas/249618799

53. Bibik, T. A., Tkachuk, I. M., Ustymenko, O. V., Ustymenko, V. V. (2011). Profesiina nadiinist viiskovosluzhbovtsiv $\mathrm{V}$ umovakh perekhodu na kontraktnyi pryntsyp komplektuvannia Zbroinykh Syl Ukrainy. Problemy viiskovoi okhorony zdorovia, 30, 22-29.

54. Profilaktyka sertsevo-sudynnykh zakhvoriuvan: adaptovana klinichna nastanova, zasnovana na dokazakh (2016). Kyiv, $127 . \quad$ : http://mtd.dec.gov.ua/images/dodatki/2016_564_PSS Z/2016_564_AKN_PSSZ.pdf

55. Rosul, M. M., Feisa, S. V., Ivano, N. V., Korabelshchykova, M. O. (2015) Profilaktyka sertsevosudynnykh zakhvoriuvan: rol simeinoho likaria. Ukraina. Zdorovia natsii, 1 (33), 178-182.

56. Radchenko, H. D., Martsovenko, I. M., Sirenko, Yu. M. (2011). Profilaktyka sertsevo-sudynnykh zakhvoriuvan - pochny z sebe. Rezultaty anonimnoho opytuvannia likariv, yaki likuiut patsiientiv $\mathrm{z}$ arterialnoiu hipertenziieiu. Ukrainskyi kardiolohichnyi zhurnal, 4, 54-58.

57. Rynda, F. P., Sytenko, O. R. (2017). Do pytannia zastosuvannia profilaktychnykh metodiv u praktychnii diialnosti likariv zahalnoi praktyky - simeinykh likariv. Ukraina. Zdorovia natsii, 4 (45), 68-72.

58. Rynda, F.P., Shafranskyi, V. V. (2017). Profilaktychna pidhotovka likariv-interniv za spetsialnistiu Zahalna praktyka - simeina medytsyna. Ukraina. Zdorovia natsii, 1 (42), 151-162.

59. Savytskyi, V. L., Vlasenko, O. M., Stryzhenko, V. I., Bulakh, O. Yu. (2014). Systema medychnoho zabezpechennia viisk (syl) - skladova zahalnoderzhavnoi polityky okhorony zdorovia hromadian Ukrainy. Nauka i oborona, 2, 27-33.

60.Stepanenko, A. V., Smiianov, V. A. (2012). Upravlinnia yakistiu medychnoi dopomohy $\mathrm{v}$ zakladi okhorony zdorovia. Skhidnoievropeiskyi zhurnal hromadskoho zdorovia, 2-3, 64-67.

61.Serdiuk, A. M., Kundiiev, Yu. I., Nahorna, A. M., Shyrobokov, V. P. (2012). Stratehiia rozvytku profilaktyky $\mathrm{v}$ okhoroni zdorovia Ukrainy. Zhurnal NAMN Ukrainy, 18 (3), 358-371.

62. Tkachuk I. M. Profilaktyka sertsevo-sudynnykh zakhvoriuvan u viiskovosluzhbovtsiv: elektronnyi posibnyk dlia likariv. Kyiv, 91 p.
63.Tkachuk I. M. Profilaktyka sertsevo-sudynnykh zakhvoriuvan $\mathrm{u}$ viiskovosluzhbovtsiv: elektronnyi posibnyk dlia molodshykh spetsialistiv z medychnoiu osvitoiu. (2018). Kyiv, 26 p.

64.Tkachuk, I. M., Moroz, H. Z. (2017). Zdorovia ta profilaktyka sertsevo-sudynnykh zakhvoriuvan $\mathrm{u}$ viiskovosluzhbovtsiv: informatsiinyi posibnyk dlia viiskovosluzhbovtsiv. Kyiv, 24 p.

65.Tkachuk, I. M., Moroz, H. Z. (2017). Rozrobka propozytsii shchodo stvorennia haluzevoho klinichnoho protokolu medychnoi dopomohy «Profilaktyka sertsevo-sudynnykh zakhvoriuvan u viiskovosluzhbovtsiv». Viiskova medytsyna Ukrainy, 2(17), 20-24.

66. Unifikovanyi haluzevyi klinichnyi protokol medychnoi dopomohy (pershoi likarskoi, kvalifikovanoi, spetsializovanoi ta nevidkladnoi) «Arterialna hipertenziia» (2014). Kyiv, 96 p.

67.Unifikovanyi klinichnyi protokol pervynnoi, vtorynnoi (spetsializovanoi) ta tretynnoi (vysokospetsializovanoi) medychnoi dopomohy. Profilaktyka sertsevo-sudynnykh zakhvoriuvan. (2016). Nakaz MOZ Ukrainy vid 13.06.2016 № 564, from: http://mtd.dec.gov.ua/index.php/uk/reiestr$\mathrm{mtd} /$ item/71-profilaktyka-sertsevosudynnykh-

zakhvoriuvan

68. Unifikovanyi klinichnyi protokol pervynnoi, vtorynnoi (spetsializovanoi) ta tretynnoi (vysokospetsializovanoi) medychnoi dopomohy. Depresiia (lehkyi, pomirnyi, tiazhkyi depresyvni epizody bez somatychnoho syndromu abo $\mathrm{z}$ somatychnym syndromom, rekurentnyi depresyvnyi rozlad, dystymiia». (2014). Nakaz MOZ Ukrainy vid 25.12.2014 № 1003, from: http://mtd.dec.gov.ua/index.php/uk/reiestr$\mathrm{mtd} /$ item/12-depresiia

69. Unifikovanyi klinichnyi protokol pervynnoi, vtorynnoi (spetsializovanoi) ta tretynnoi (vysokospetsializovanoi) medychnoi dopomohy. Reaktsiia na vazhkyi stres ta rozlady adaptatsii. Posttravmatychnyi stresovyi rozlad (2016) nakaz MOZ Ukrainy № 121 vid 23.12.2016, from: http://mtd.dec.gov.ua/index.php/uk/reiestr-

$\mathrm{mtd} /$ item/60-posttravmatychnyi-stresovyi-rozlad

70.Unifikovanyi klinichnyi protokol pervynnoi, ekstrenoi ta vtorynnoi (ekstrenoi) medychnoi dopomohy. Arterialna hipertenziia. (2012). Nakaz MOZ vid 24.05.2012№384, from: http://mtd.dec.gov.ua/images/dodatki/384_2012/38 4_2012ykpmd_ag.pdf

71.Shekera, O. H. (2015). Kontseptualni polozhennia shchodo reformuvannia medychnoho zabezpechennia Zbroinykh Syl Ukrainy. Zdorovia suspilstva, 1-2, 85-92.

72.Shekera, O. H. (2016). Pidvyshchennia vzaiemosumistnosti mizh medychnym zabezpechenniam zbroinykh syl Ukrainy ta NATO. Zdorovia suspilstva, 3-4, 56-63.

73. Shekera, O. H. (2009). Stratehichnyi kurs medychnoho zabezpechennia zbroinykh syl krain NATO. Visnyk naukovoho informatsiino-analitychnoho 
tsentru NATO Prykarpatskoho natsionalnoho universytetu imeni Vasylia Stefanyka, 2, 158-164.

74. Shekera, O. H., Krasnov, V. V. (2013). Rozroblennia kompetentnisnoi modeli likaria zahalnoi praktyky-simeinoho likaria. Simeina medytsyna, 6, 21-23.

75.Shekera, O. H., Yablonskyi, P. M. (2013). Zastosuvannia optymalnoi modeli dyspanseryzatsii viiskovosluzhbovtsiv pry planuvanni profilaktychnoi diialnosti likaria zahalnoi praktyky - simeinoi medytsyny. Simeina medytsyna. 2013, 1, 18-22.

76. Lashkul, Z. V., Posnyi, V. S., Avramenko, V. S., Odrynskyi, V. A. (2012). Shkola zdorovia, yak suchasna tekhnolohiia vtorynnoi profilaktyky arterialnoi hipertenzii $\mathrm{v}$ pervynnii lantsi okhorony zdorovia: navchalno-metodychnyi posibnyk. Kyiv, 49 p.

77.AJP 4.10 (B). (2015). Allied joint medical support doctrine. Brussels: Supreme Headquarters of Allied Powers in Europe.
78. Allied Joint Publication-4.10 (B). (2015). Allied Joint Doctrine for Medical Support. Edition B Version 1 with UK National elements, from: https://assets.publishing.service.gov.uk/government/ uploads/system/uploads/attachment_data/file/4571 42/20150824-AJP_4_10_med_spt_uk.pdf

79. MC 326/3. NATO principles and policies of operational medical support. (2011).

80.Mancia G. et al. (2013). 2013 ESH/ESC Guidelines for the management of arterial hypertension. The Task Force for the management of arterial hypertension of the European Society of Hypertension (ESH) and of the European Society of Cardiology (ESC) / European Heart Journal, 34 (28), 2159-2219. https://doi.org/10.1093/eurheartj/eht151

\title{
ОБЗОР СОВРЕМЕННЫХ АСПЕКТОВ ПРОФИЛАКТИКИ СЕРДЕЧНО-СОСУДИСТЫХ ЗАБОЛЕВАНИЙ У ВОЕННОСЛУЖАЩИХ ВООРУЖЕННЫХ СИЛ УКРАИНЫ
}

\author{
Т. В. Куц, Г. З. Мороз, И. М. Ткачук
}

Украинская военно-медицинская академия, г. Киев, Украина

Цель исследования: провести анализ и обобщение данных литературных источников о состоянии профилактики сердечно-сосудистых заболеваний у военнослужащих Вооруженных сил Украины на современном этапе.

Материалы и методы. Аналитическая база данных включает 80 научных работ, в том числе нормативно-правовые документы и статически-справочные материалы (из них 4 - англоязычные). Обзор литературы выполнен $c$ использованием системного подхода и системного анализа, библиосемантического метода.

Результаты. Обзор литературы показал положительные тенденции в системе профилактики серцечно-судистых заболеваний у военнослужащих вооруженных Сил Украины, а именно: разработана и внедрена функціонально-организационная модель профилактики сердечно-сосудистых заболеваний у военнослужащих на уровне первичной медицинской помощи; разработано учебно-методическое обеспечение для усовершенствования підготовки военных врачей общей практики -симейной медицины и младших специалистов с медицинским образованием по вопросам профілактики сердечно-сосудистых заболеваний; внедрено методическое обеспечение повышения информированности военнослужсщих по вопросам здорового образа жизни; создана на базе Клиники амбулаторной помощи Национального военномедицинского клинического центра «ГВКГ» «Школы здоров'я для больных с артериальной гипертензией и коморбидными тривожно-депрессивными расстройствами» и внедрен комплексный поход к организации лечения и реабилитации военнослужащих-участников боевых действий с артериальной гипертензией. Остаються нерешенными вопросы: существует необходимость создания локального клинического протокола по профилактике сердечно-сосудистых заболеваний; не регламентировано проведение виявления факторов риска сердечно-сосудистых заболеваний призывникам на уровне военных комиссариатов; не определена роль и место гражданских учреждений охраны здоровья и образования, общественных и волонтерских организаций в реализации профилактики сердечно-сосудистых заболеваний в период до призыва в ряды Вооруженных сил Украины.

Выводы. Обобщение современных научных данных показало, что существующая система профилактики серцено-сосудистных заболеваний у военнослужащих требует усовершенствований в соответствии со стандартами НАТО, где наиболее важное место занимают превентивные мероприятия.

ключевые слова: профилактика, сердечно-сосудистые заболевания, военнослужащие.

\section{THE REVIEW OF MODERN ASPECTS OF CARDIOVASCULAR DISEASES PREVENTION AMONG MILITARY PERSONNEL OF THE ARMED FORCES OF UKRAINE}

\section{T. V. Kuts, G. Z. Moroz, I. M. Tkachuk}

Ukrainian Military Medical Academy, Kiev, Ukraine.

The purpose of the study is to analyze and summarize the data from literary sources on the state of the prevention of cardiovascular diseases among the military personnel of the Armed Forces of Ukraine at the present stage. 
Materials and methods. The analytical base of data is formed from 80 scientific projects, including normative legal documents and statistically significant materials (4 of them are English ones). The review of the literature is based on the results of the system approach and system analysis, bibliosemantic method.

Results. A review of the literature showed positive trends in the system of prevention of cardiovascular diseases among the servicemen of the Armed Forces of Ukraine, namely: developed and implemented the functional and organizational model the cardiovascular disease prevention among the military personnel of the Armed Forces of Ukraine at the level of primary medical care; developed educational and methodological support for improving the training for the military general practitioners-family medicine and the junior specialists with medical education for the cardiovascular disease prevention; methodological support for raising the awareness among the servicemen for the healthy lifestyle issues has been introduced; established on the basis of the Outpatient Clinic Department of the National Military Medical Clinical Center "GVKG" "School of Health for patients with hypertension and comorbid anxiety and depressive disorders"; the effectiveness of the integrated approach to the treatment and rehabilitation among military personnel who had participated in the antiterrorist operation with arterial hypertension and comorbid pathology, introduced in the day care center of Outpatient clinic department at the National Military Medical Clinical Center "The Main Military Clinical Hospital", has been proved. However, there are a number of issues that need to be addressed: it is necessary to create a local clinical protocol for the cardiovascular disease prevention among the military; identification of risk factors for cardiovascular diseases for conscripts at the level of military commissariats is not regulated; the role and place of civilian health care and educational institutions, public and volunteer organizations in the implementation for the cardiovascular diseases prevention in the period before conscription into the Armed Forces of Ukraine has not been determined.

Conclusions. The generalization of modern scientific data showed that the existing system for the prevention of cardio-vascular diseases among the military personnel requires improvements in accordance with NATO standards, where the most important place is taken by preventive measures.

Key words: prophylaxis, cardiovascular diseases, military personnel.

Конфлікт інтересів. Автори не заявляють конфлікту інтересів.

Conflicts of interest: authors have no conflict of interest to declare.

\section{Відомості про авторів:}

Куц Т.В.Е, - підполковник медичної служби, кандидат медичних наук, доцент, заступник начальника кафедри військової загальної практики-сімейної медицини Української військово-медичної академії, м. Київ, Україна

Мороз Г.3. А,, C,D,E, - доктор медичних наук, професор, професор кафедри військової загальної практики-сімейної медицини Української військово-медичної академії, м. Київ, Україна

Ткачук I. М. A,B,C,D,E,F - доктор медичних наук, доцент кафедри військової загальної практикисімейної медицини Української військово-медичної академії, м. Київ, Україна

$A$ - концепція та дизайн дослідження; B - збір даних; $C$ - аналіз та інтерпретація даних;

$D$ - написання статmi; $E$ - редагування статmi; F- остаточне затвердження статті.

Сведения об авторах:

Куц Т.В. - подполковник медицинской службы, кандидат медицинских наук, доцент, заместитель начальника кафедры военной общей практики- семейной медицины Украинской военно-медицинской академии, г. Киев, Украина.

Мороз Г. 3. - доктор медицинских наук, профессор, профессор кафедры военной общей практикисемейной медицины Украинской военно-медицинской академии, г. Киев, Украина.

Ткачук И. М. - доктор медицинских наук, доцент кафедры военной общей практики-семейной медицины Украинской военно-медицинской академии, г. Киев, Украина.

Information about authors:

Kuts T.V.E,F -LTC, MS, PHD, Associate Professor, Deputy Head of department of Military General Practice and Family Medicine of the Ukrainian Military Medical Academy, Kyiv, Ukraine. E-mail: taraskuts@gmail.com, https://orcid.org/0000-0001-7619-3679

Moroz G.Z.A,C,D,E,F - MD, professor, Professor of the department of Military General Practice and Family Medicine of the Ukrainian Military Medical Academy, Kyiv, Ukraine. E-mail: moroz_galina@i.ua, https://orcid.org/0000-0003-4329-7193

Tkachuk I.M. A,B,C,D,E,F - MD, Associate Professor of the department of Military General Practice and Family Medicine of the Ukrainian Military Medical Academy, Kyiv, Ukraine. E-mail: iryna tkachuk@i.ua, https://orcid.org/0000-0001-6363-6821

$A$ - research concept and design; $B$ - collection and/or assembly of data; $C$ - data analysis and interpretation;

$D$ - writing the article; $E$ - critical revision of the article; $F$ - final approval of the article.

Адреса для листування: вул. Московська, 45/1, буд. 33, м. Київ 01015 